\title{
PERENCANAAN PERSEDIAAN ALAT TULIS KANTOR DI CV SURYA NIAGA JAYA
}

\author{
Riyan Hidayat ${ }^{(1)}$, Juni \\ Saputra ${ }^{(2)}$, Amiroel Oemara \\ Syarif $^{(3)}$ \\ 1,2,3) Program Studi Teknik Industri, \\ Sekolah Tinggi Teknologi Dumai \\ Jl. Utama Karya Bukit Batrem II \\ Email: Riyangaskins@gmail.com; \\ junisaputr4@gmail.com; \\ oemara.syarief@gmail.com
}

\begin{abstract}
ABSTRAK
CV Surya Niaga Jaya merupakan salah satu perusahaan yang bergerak dibidang supplier penjualan alat tulis kantor. CV Surya Niaga Jaya memiliki kendala terhadap pengelolaan persediaan yaitu terjadi kenaikan permintaan alat tulis kantor, untuk (reorder) mengalami masalah permintaan yang tidak terlayani harus menjadi perhatian bagi CV Surya Niaga Jaya karena hal ini akan berpengaruh pada terhambatnya kegiatan operasional penjualan. Dengan menggunakan metode peramalan (forecasting) dan EOQ (economic order quantity) sebagai teknik pemecahan permasalahan. Untuk dapat dilakukan analisa apabila ada terjadi penumpukan atau kekurangan persediaan, dan berapa jumlah safety stock dan maksimum stok yang harus disiapkan perusahaan untuk kelancaran produksi. Persediaan pena di CV Surya Niaga Jaya periode Januari 2021 adalah sebanyak 45 kotak, jumlah EOQ untuk pena adalah 26 kotak dengan 6 kotak safety stock dan maksimum stok 47 kotak. Pemesanan kembali sebesar 32 kotak dan untuk ROP adalah 7 kotak. Sedangkan untuk persediaan kertas di CV Surya Niaga Jaya periode Januari 2021 adalah sebanyak 128 kotak, jumlah EOQ untuk kertas adalah 45 kotak dan jumlah Safety Stock sebanyak 17 kotak dan untuk maksimum stok sebesar 105 kotak. Pemesanan kembali sebesar 62 kotak dan untuk ROP adalah 20 kotak.
\end{abstract}

Kata-kunci: Economic Order Quantity, Forecasting,

Persediaan.

\section{ABSTRACT}

CV Surya Niaga Jaya is a company engaged in the supplier of office stationery sales. CV Surya Niaga Jaya has problems with inventory management, namely an increase in demand for office stationery, to (reorder) experiencing unserved demand problems must be a concern for CV Surya Niaga Jaya because this will affect the obstruction of sales operational activities. By using forecasting and EOQ (economic order quantity) methods as problem solving techniques. To be able to do an analysis if there is an accumulation or shortage of inventory, and what is the amount of safety stock and the maximum stock that the company must prepare for smooth production. The pens stock in CV Surya Niaga Jaya for the period of January 2021 is 45 boxes, the total of EOQ for pens stock is 26 boxes with 6 boxes of safety stock and a maximum stock of pen is 47 boxes. Reorder for 32 boxes of pen and for ROP is 7 boxes of pen. Meanwhile, the paper inventory in CV Surya Niaga Jaya for the period of January 2021 was 128 boxes, the number of EOQ for paper was 45 boxes and the total safety stock was 17 boxes and for a maximum stock of 105 boxes. Order back is 62 boxes and for ROP is 20 boxes.

Keywords: Economic Order Quantity, Forecasting, Inventory 


\section{Pendahuluan}

CV Surya Niaga Jaya merupakan salah satu perusahaan yang bergerak dibidang supplier penjualan alat tulis kantor di Kota Dumai, Riau. CV Surya Niaga Jaya menjual alat tulis kantor dengan mitra kerjanya seperti sekolah dan perusahaan dan instansi pemerintah yang ada di kota Dumai. Dan CV Surya Niaga Jaya menjual banyak jenis alat tulis kantor yang diantaranya kertas, map, buku, pena, penggaris, tipe-x, bolpoint, amplop dan sebagainya. Dalam memenuhi kebutuhan mitra kerja dan konsumen terhadap kebutuhan alat tulis kantor, CV Surya Niaga Jaya memiliki kendala terhadap pengelolaan persediaan yaitu terjadi kenaikan permintaan alat tulis kantor terutama pada produk pena dan kertas oleh mitra kerja dan dimasa pandemi, Covid-19, untuk

(reorder) mengalami masalah permintaan yang tidak terlayani harus menjadi perhatian bagi CV Surya Niaga Jaya karena hal ini akan berpengaruh pada terhambatnya kegiatan operasional penjualan yang akan mengakibatkan menurunnya mutu pelayanan kepada konsumen. Hal ini membuat perusahaan sulit menentukan persediaan alat tulis kantor pena dan kertas dalam jangka waktu panjang maupun jangka waktu pendek karena penjualan yag tidak stabil. Untuk itu CV Surya Niaga Jaya harus mempredisi alat ulis kantor berupa pena daa kerta untuk memenuhi kebutuhan pelanggan dan tidak terjadi kelebihan atau kekurangan pada inventorinya yang mana akan mempengaruhi biaya operasional dan profit perusahaan tersebut. Untuk mewujudkan keberhasilan perusahaan dalam penjualan alat tulis kantor maka CV Surya Niaga Jaya melakukan penelitian terhadap persediaan pena dan kertas dimasa yang akan datang.

Berdasarkan permasalah dilatar belakang Penulis menggunakan metode peramalan (forecasting) dan EOQ (economic order quantity) sebagai teknik pemecahan permasalahan. Dengan metode tersebut persediaan dapat dilakukan analisa apabila ada terjadi penumpukan atau kekurangan persediaan, dan berapa jumlah safety stock dan maksimum stok yang harus disiapkan perusahaan untuk kelancaran produksi. Oleh karena itu Penulis mengangkat judul mengenai perencanaan persediaan alat tulis kantor di CV Surya Niaga Jaya.

\section{Metode Penelitian}

Populasi merupakan keseluruhan anggota atau kelompok yang membentuk objek yang dikenakan investigasi oleh peneliti menurut Sinulingga, (2015). Maka populasi dalam penelitian ini adalah data penjualan pena dan kertas di CV Surya Niaga Jaya. Metode rata-rata bergerak, rata-rata bergerak terbobot, pemulusan eksponensial, analisis garis kecenderungan, pemulusan eksponensial dengan mempertimbangkan kecenderungan, dan model peramalan dengan mempertimbangkan pengaruh musiman merupakan metode dengan teknik peramalan kuantitatif statistik yang pada umumnya menggunakan data historis yang menitik beratkan pada perubahan pola. Untuk menghitung kesalahan peramalan dengan menggunakan MAD (mean absolute devition). Penelitian ini juga menggunakan metode EOQ menurut Harmono, (2014) untuk mengendalikan persediaan pena dan kertas di CV Surya Niaga Jaya

Adapun langkah-langkah yang digunakan sebelum menentukan metode forecast yang digunakan adalah sebagai berikut:

1. Identifikasi pola historis dari data aktual penjualan 
2. Memilih metode forecast yang sesuai dengan pola historis dari data aktual penjualan.

3. Melakukan analisis data berdasarkan model forecast yang dipilih.

4. Memilih model forecasting yang tepat berdasarkan kesalahan terkecil.

5. Memeriksa keandalan model forecast yang dipilih berdasarkan peta kontrol tracking signal.

6. Data peramalan bisa dijadikan sebagai dasar untuk menghitung persediaan/EOQ.

7. Dari EOQ bisa ditentukan berapa pena dan kertas yang harus disediakan dengan cost terkecil.

\section{Hasil dan Pembahasan}

Data yang dikumpulkan adalah data penjualan kertas dan pena selama 36 periode. Data penjualan kertas dan pena dapat dilihat pada Tabel 1.

Tabel 1. Rekapitulasi Data Penjualan Kertas dan Pena tahun 2018 sampai 2020 (unit).

\begin{tabular}{|c|c|c|c|c|c|c|}
\hline \multirow{2}{*}{ Periode } & Pena & Kertas & Pena & Kertas & Pena & Kertas \\
\hline & \multicolumn{2}{|c|}{2018} & \multicolumn{2}{|c|}{2019} & \multicolumn{2}{|c|}{2020} \\
\hline Januari & 64 & 111 & 50 & 50 & 63 & 88 \\
\hline Februari & 52 & 90 & 42 & 42 & 66 & 75 \\
\hline Maret & 54 & 87 & 30 & 30 & 54 & 87 \\
\hline April & 58 & 93 & 52 & 54 & 60 & 69 \\
\hline Mei & 64 & 112 & 58 & 58 & 63 & 75 \\
\hline Juni & 63 & 81 & 53 & 53 & 52 & 103 \\
\hline Juli & 48 & 98 & 48 & 48 & 66 & 114 \\
\hline Agustus & 62 & 82 & 62 & 62 & 48 & 120 \\
\hline September & 53 & 102 & 58 & 58 & 63 & 100 \\
\hline Oktober & 55 & 95 & 49 & 49 & 53 & 115 \\
\hline November & 64 & 84 & 61 & 61 & 67 & 117 \\
\hline Desember & 52 & 79 & 68 & 68 & 43 & 131 \\
\hline
\end{tabular}

Sumber: CV Surya Niaga Jaya, 2020

Setelah melakukan peramalan dilanjutkan mengukur tingkat kehandalan dengan tracking signal. Pemulusan dengan $\alpha=0,9$ inilah yang terpilih karena tracking signal dengan possitive error dan negative error yang sama banyak. Hasil perhitungan peramalan untuk pena dapat dilihat pada Tabel 2.

Tabel 2. Forecast Model Pemulusan Eksponensial dengan Konstanta Pemulusan $(\alpha)=0,9$

\begin{tabular}{|l|r|r|r|}
\hline \multicolumn{1}{|c|}{ Bulan Tahun } & $\begin{array}{c}\text { Indeks } \\
\text { Waktu (t) }\end{array}$ & Penjualan Aktual (A) & $\begin{array}{c}\text { Ramalan berdasarkan ES }(\alpha= \\
0,9) \\
(\mathrm{F}, \mathrm{ES} \alpha=0,9)\end{array}$ \\
\hline Januari 2018 & 1 & 64 & 56 \\
\hline Februari 2018 & 2 & 52 & $63+0,9(64-56)=63$ \\
\hline Maret 2018 & 3 & 54 & $53+0,9(54-53)=54$ \\
\hline April 2018 & 4 & 58 & $54+0,9(58-54)=58$ \\
\hline Mei 2018 & 5 & 64 & $58+0,9(64-58)=63$ \\
\hline Juni 2018 & 6 & 63 & $63+0,9(63-63)=63$ \\
\hline Juli 2018 & 7 & 48 & \\
\hline
\end{tabular}


Tabel 2. Forecast Model Pemulusan Eksponensial dengan Konstanta Pemulusan $(\alpha)=0,9($ Lanjutan $)$

\begin{tabular}{|l|r|r|r|}
\hline Bulan Tahun & $\begin{array}{r}\text { Indeks } \\
\text { Waktu (t) }\end{array}$ & Penjualan Aktual (A) & $\begin{array}{r}\text { Ramalan berdasarkan ES }(\alpha= \\
0,9) \\
(\mathrm{F}, \mathrm{ES} \alpha=0,9)\end{array}$ \\
\hline Agustus 2018 & 8 & 62 & $63+0,9(48-63)=50$ \\
\hline September 2018 & 9 & 53 & $50+0,9(62-50)=61$ \\
\hline Oktober 2018 & 10 & 55 & $61+0,9(53-61)=54$ \\
\hline November 2018 & 11 & 64 & $54+0,9(55-54)=55$ \\
\hline Desember 2018 & 12 & 52 & $55+0,9(64-55)=63$ \\
\hline Januari 2019 & 13 & 50 & $63+0,9(52-63)=53$ \\
\hline Februari 2019 & 14 & 42 & $53+0,9(50-53)=50$ \\
\hline Maret 2019 & 15 & 30 & $50+0,9(52-50)=43$ \\
\hline April 2019 & 16 & 52 & $43+0,9(30-43)=31$ \\
\hline Mei 2019 & 17 & 58 & $31+0,9(54-31)=52$ \\
\hline Juni 2019 & 18 & 53 & $52+0,9(58-52)=57$ \\
\hline Juli 2019 & 19 & 48 & $57+0,9(53-57)=53$ \\
\hline Agustus 2019 & 20 & 62 & $53+0,9(48-53)=49$ \\
\hline September 2019 & 21 & 58 & $49+0,9(62-49)=61$ \\
\hline Oktober 2019 & 22 & 49 & $61+0,9(58-61)=58$ \\
\hline November 2019 & 23 & 61 & $58+0,9(49-58)=50$ \\
\hline Desember 2019 & 24 & 68 & $50+0,9(61-50)=60$ \\
\hline Januari 2020 & 25 & 63 & $60+0,9(68-60)=67$ \\
\hline Februari 2020 & 26 & 66 & $67+0,9(63-67)=63$ \\
\hline Maret 2020 & 27 & 54 & $63+0,9(66-63)=66$ \\
\hline April 2020 & 28 & 60 & $66+0,9(54-66)=55$ \\
\hline Mei 2020 & 29 & 63 & $55+0,9(60-55)=60$ \\
\hline Juni 2020 & 30 & 52 & $60+0,9(63-60)=63$ \\
\hline Juli 2020 & 31 & 66 & $63+0,9(52-63)=53$ \\
\hline Agustus 2020 & 32 & 48 & $53+0,9(66-53)=65$ \\
\hline September 2020 & 33 & 63 & $65+0,9(48-65)=50$ \\
\hline Oktober 2020 & 34 & 53 & $50+0,9(63-50)=62$ \\
\hline November 2020 & 35 & 67 & $62+0,9(53-62)=54$ \\
\hline Desember 2020 & 36 & 43 & $54+0,9(67-54)=66$ \\
\hline Januari 2021 & 37 & 6 & $66+0,9(43-66)=45$ \\
\hline Sumber: Pengata & & & \\
\hline
\end{tabular}

Sumber: Pengolahan Data, 2020

Tabel 2 merupakan peramalan dengan menggunakan metode pemulusan eksponensial kita dapat mengetahui hasil forecast dimasa yang akan datang yaitu 54 kotak. Untuk mengetahui sejauh mana keandalan dari model peramalan yang digunakan, langkah selanjutnya adalah membuat peta kontrol tracking signal. Perhitungan nilai-nilai tracking signal untuk model pemulusan eksponensial dengan konstanta pemulusan $\alpha=0.9$. Hasil perhitungan model exponential smoothing (ES, $\alpha=$ $0,9)$ dapat dilihat pada lampiran. Untuk mengetahui sejauh mana keandalan dari model forecast yang digunakan, Langkah selanjutnya adalah menguji keandalan forecast atau peramalan menggunakan peta kontrol tracking signal. Perhitungan tracking signal untuk model exponential smoothing yang dapat dihitung dengan cara:

a. Nilai Error

Error $=$ Aktual - Forecast $=43-66=-23$

b. Nilai RSFE

RFSE $=$ Kumulatif nilai error $=-12$

c. Absolut Error

Absolut error $=$ nilai mutlak dari error $=23$ 
d. Kumulatif Absolut Error

Kumulatif absolut error $=320$

e. Nilai Mean Absolute Deviation (MAD)

MAD = Kumulatif absolut error (kumulatif) / Periode

$\mathrm{MAD}=7 / 1=9$

f. Tracking Signal

Tracking signal $=\mathrm{RSFE} / \mathrm{MAD}=5 / 8=-1,35$

Hasil perhitungan tracking signal untuk model pemulusan eksponensial $\alpha=0,9$ ditunjukkan pada lampiran. Untuk grafik tracking signal dari model pemulusan eksponensial $(\alpha=0,9)$ dapat dilihat pada Gambar 1 .

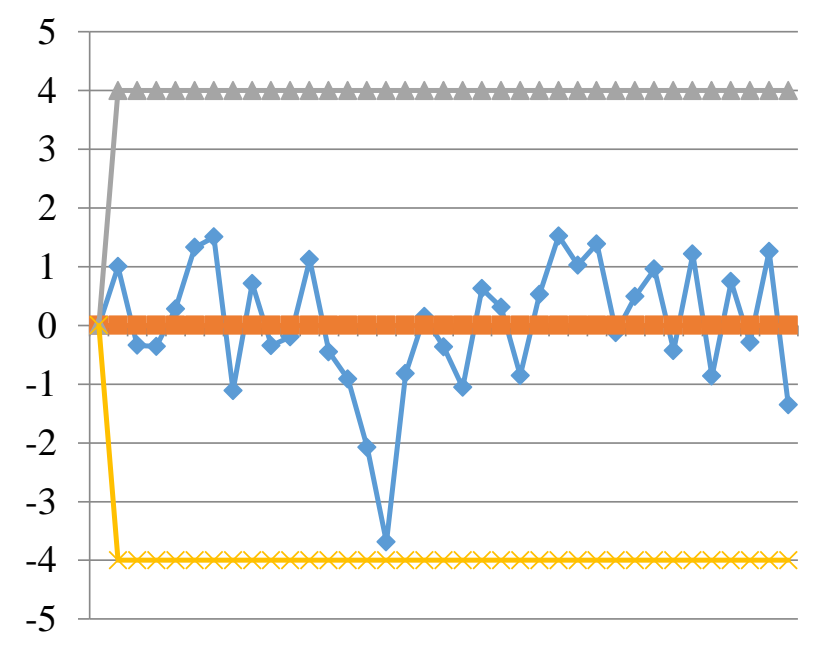

Gambar 1. Peta Kontrol Tracking Signal Exponential Smoothing $(\alpha=0,9)$

Sumber: Pengolahan Data, 2020

Gambar 1 menunjukkan bahwa nilai-nilai tracking signal untuk model forecast dengan menggunakan metode pemulusan eksponensial dengan menggunakan konstanta pemulusan $\alpha=0,9$ berada dalam batas-batas yang dapat diterima (maksimum \pm 4 ), dimana nilai-nilai tracking signal itu bergerak dari $-3,59$ sampai $+1,52$. Hal ini menunjukkan bahwa akurasi dari model pemulusan eksponensial dapat diandalkan. Berdasarkan pengujian kehandalan dari model pemulusan eksponensial (Exponensial Smoothing) menggunakan tracking signal, penulis memutuskan untuk menggunakan model pemulusan eksponensial (exponensial smoothing) sebagai metode forecasting yang tepat untuk memprediksi penjualan pena untuk periode kedepannya dengan nilai ramalan 54 kotak. Selanjutnya grafik perbandingan nilai aktual dan peramalan penjualan pena (exponential smoothing $\alpha=0,9$ ) dapat dilihat pada Gambar 1. 


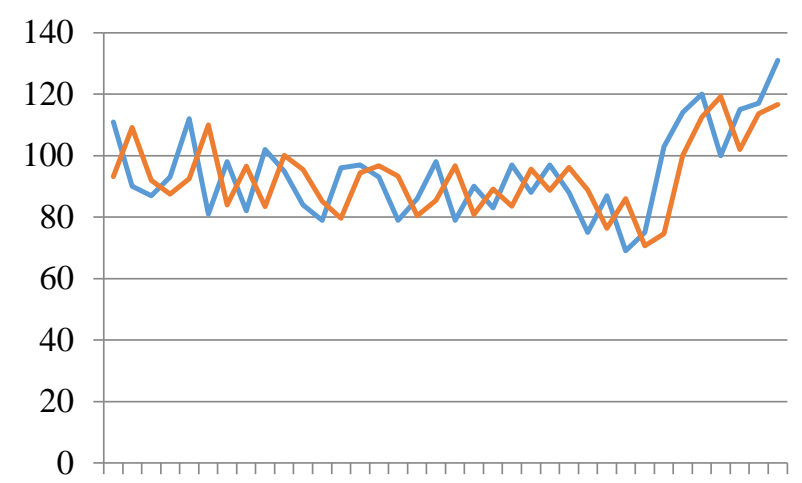

Gambar 2. Grafik Perbandingan Nilai Penjualan Aktual dan Hasil Forecast

Sumber: Pengolahan Data, 2020

Gambar 2 merupakan grafik perbandingan nilai aktual dan hasil peramalan penjualan pena periode Januari 2018 sampai Desember 2020. Dimana nilai aktual dan ramalan tersebut hampir mirip dan berada dalam batas-batas yang dapat diterima. Sehingga metode ini cocok digunakan untuk menentukan nilai penjualan kertas periode berikutnya Setelah melakukan pengolahan data dan perhitungan hasil peramalan menggunakan model pemulusan pemulusan eksponensial untuk bulan Januari 2021 sebesar 45 kotak. Maka jumlah estimasi kebutuhan jumlah pena untuk 1 tahun ke depan adalah 45 x 12 = 540 kotak. Langkah selanjutnya ialah membuat persamaan untuk ratarata persediaan.

Rata-rata Persediaan $=\frac{\text { persediaan }+ \text { persediaan akhir }}{2}$

$$
=\frac{(\mathrm{Q}+0)}{2}=\mathrm{Q} / 2
$$

Jadi, persamaan untuk rata-rata persediaan yaitu $Q / 2$. Selanjutnya mencari persamaan untuk rata-rata biaya simpan.

Rata-rata biaya simpan $=\mathrm{Q} / 2 \times \mathrm{h}=\mathrm{Q} / 2 \times 31.000=15.500 \mathrm{Q}$

Persamaan untuk rata-rata biaya simpan yaitu 15.500 Q. Selanjutnya mencari persamaan untuk total biaya pemesanan.

Total biaya pemesanan $=\mathrm{A} \frac{\mathrm{D}}{\mathrm{Q}}$

$$
=20.000 \frac{540}{\mathrm{Q}}=10.800 .000 / \mathrm{Q}
$$

Persamaan untuk total biaya pemesanan adalah 10.800.000/Q. Lalu menghitung total biaya yang harus dikeluarkan dengan rumus:

Total Biaya $=$ Biaya simpan + biaya pesan

$$
=15.500 \mathrm{Q}+10.800 .000 / \mathrm{Q}
$$

Jadi, persamaan untuk total biaya menjadi $15.500 \mathrm{Q}+10.800 .000 / \mathrm{Q}$.

Selanjutnya menghitung EOQ untuk pena dengan rumus:

$\mathrm{EOQ}=\sqrt{\frac{2 \mathrm{AD}}{\mathrm{h}}}=\sqrt{\frac{2 \times 20.000 \times 540}{31.000}}=\sqrt{\frac{21.600 .000}{31.000}}=\sqrt{697}=26$ kotak

Jdi EOQ untuk pena adalah sebanyak 26 kotak. Selanjutnya untuk perhitungan persediaan dapat dilihat pada Tabel 3.

Tabel 3. Hitungan Biaya Persediaan 


\begin{tabular}{|r|r|r|r|}
\hline $\begin{array}{c}\text { Kuantitas pesanan } \\
(\mathrm{Q})\end{array}$ & $\begin{array}{c}\text { Biaya simpan } 15.500 \\
\mathrm{Q}\end{array}$ & $\begin{array}{c}\text { Biaya pesanan } \\
10.800 .000 / \mathrm{Q}\end{array}$ & Total biaya \\
\hline 22 & 341000 & 490909 & 831909 \\
\hline 23 & 356500 & 469565 & 826065 \\
\hline 24 & 372000 & 450000 & 822000 \\
\hline 25 & 387500 & 432000 & 819500 \\
\hline 26 & 403000 & 415385 & 818385 \\
\hline 27 & 418500 & 400000 & 818500 \\
\hline 28 & 434000 & 385714 & 819714 \\
\hline 29 & 449500 & 372414 & 821914 \\
\hline 30 & 465000 & 360000 & 825000 \\
\hline 31 & 480500 & 348387 & 828887 \\
\hline
\end{tabular}

Sumber: Pengolahan Data, 2020

Tabel 3 menunjukkan bahwa banyaknya pesanan yang paling ekonomis sebanyak 26 kotak, hal ini terbukti total biaya pengelolaan persediaan, yang menunjukkan perhitungan biaya pesan dan biaya simpan yang paling efisien, yaitu sebesar Rp. 818.385,-. Setelah diketahui kuantitas pesanan Q untuk pena pada tingkat EOQ, melengkapi model ini dibutuhkan penentuan waktu tunggu (lead time) antara waktu pesan sampai barang diterima. Misalnya, masa tunggu dalam waktu 4 hari sejak barang dipesan sampai diterima digudang. Oleh karena adanya waktu tunggu (lead time) maka dibutuhkan adanya persediaan yang dicadangkan untuk masa tunggu jangan sampai persediaan dalam kondisi kosong baru memesan barang, karena kondisi ini akan mengganggu kesinambungan proses penjualan. Oleh karena itu, perusahaan membutuhkan persediaan pengaman. Besarnya bisa ditentukan berdasarkan masa tunggu pesanan melalui persamaan, yaitu:

Persediaan pengaman $=\frac{\mathrm{D}}{360} \times$ lead time

Persediaan pengaman $=\frac{540}{360} \times 4$ hari $=6$ kotak

Dengan demikian, pemesanan kembali yaitu pada kondisi tingkat persediaan pengaman ditambah kuantitas pemesanan pada tingkat EOQ yaitu sebesar $26+6=32$ kotak. Selanjutnya menghitung reoder point (ROP) yaitu titik jumlah pemesanan kembali atau untuk menentukan berapa batas minimal tingkat persediaan yang harus dipertimbangkan sehingga tidak terjadi kekurangan.

$\mathrm{ROP}=\mathrm{D} \times \mathrm{L}=(540 / 312) \times 4=7$ kotak

Artinya CV Surya Niaga Jaya harus melakukan pemesanan pena pada waktu jumlah persediaan pena tinggal 7 kotak. Selanjutnya perhitungan untuk maksimum stok adalah sebagai berikut:

Maksimum stok $=\mathrm{EOQ}+\mathrm{SS}+\mathrm{z}$

$\mathrm{z}$ didapat dari kebutuhan selama lead time yaitu:

$\mathrm{z}=\mathrm{L} \times \frac{\mathrm{S}}{12}=4 \times \frac{45}{12}=15$ kotak

Maka maksimum stok $=26+6+15=47$ kotak. 
Selanjutnya grafik pengendalian persediaan pena di CV Surya Niaga Jaya dapat dilihat pada Gambar 3.

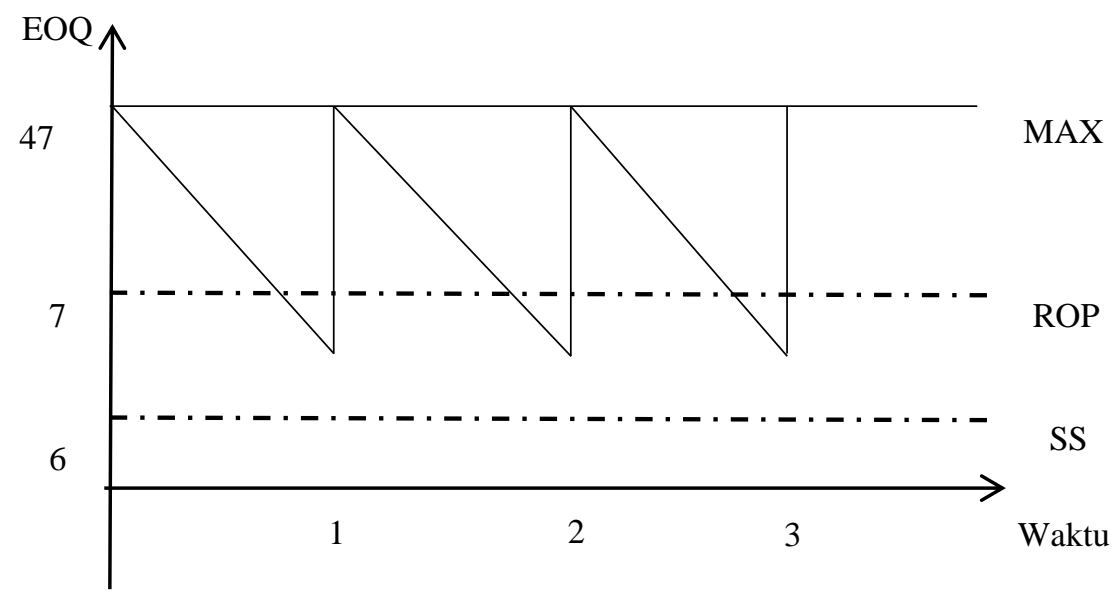

Gambar 3. Grafik Pengendalian Persediaan Pena

Sumber: Pengolahan Data, 2020

Gambar 3 menunjukkan bahwa jumlah maksimum stok kebutuhan pena bulan November sebanyak 47 kotak, untuk melakukan pemesanan kembali pada saat jumlah pena didalam gudang sebanyak 7 kotak dan jumlah safety stock sebanyak 6 kotak dengan lead time 4 hari untuk bisa dilakukan pengadaan persediaan. Setelah melakukan peramalan dilanjutkan mengukur tingkat kehandalan dengan tracking signal. Pemulusan dengan $\alpha=0,8$ inilah yang terpilih karena memiliki tracking signal dengan possitive error dan negative error yang sama banyak. Hasil perhitungan peramalan untuk Kertas dapat dilihat pada Tabel 4.

Tabel 4. Forecast Model Pemulusan Eksponensial dengan Konstanta Pemulusan $(\alpha)=0,8$

\begin{tabular}{|l|r|r|r|}
\hline \multicolumn{1}{|c|}{ Bulan Tahun } & $\begin{array}{c}\text { Indeks Waktu } \\
(\mathrm{t})\end{array}$ & Penjualan Aktual (A) & $\begin{array}{c}\text { Ramalan berdasarkan ES }(\alpha= \\
0,8) \\
(\mathrm{F}, \text { ES } \alpha=0,8)\end{array}$ \\
\hline Januari 2018 & 1 & 111 & 93 \\
\hline Februari 2018 & 2 & 90 & $93+0,8(111-93)=107$ \\
\hline Maret 2018 & 3 & 87 & $107+0,8(90-107)=93$ \\
\hline April 2018 & 4 & 93 & $93+0,8(87-93)=88$ \\
\hline Mei 2018 & 5 & 112 & $88+0,8(93-88)=92$ \\
\hline Juni 2018 & 6 & 81 & $92+0,8(112-92)=108$ \\
\hline Juli 2018 & 7 & 98 & $108+0,8(81-108)=86$ \\
\hline Agustus 2018 & 8 & 82 & $86+0,8(98-86)=96$ \\
\hline September 2018 & 9 & 102 & $95+0,8(82-96)=85$ \\
\hline Oktober 2018 & 10 & 95 & $85+0,8(102-85)=99$ \\
\hline November 2018 & 11 & 84 & $99+0,8(95-99)=96$ \\
\hline Desember 2018 & 12 & 79 & $96+0,8(84-96)=86$ \\
\hline Januari 2019 & 13 & 96 & $86+0,8(79-86)=80$ \\
\hline Februari 2019 & 14 & 97 & $80+0,8(96-80)=93$ \\
\hline Maret 2019 & 15 & 93 & $93+0,8(97-93)=96$ \\
\hline April 2019 & 16 & 79 & $96+0,8(93-96)=94$ \\
\hline
\end{tabular}


Tabel 4.. Forecast Model Pemulusan Eksponensial dengan Konstanta Pemulusan $(\alpha)=0,8($ Lanjutan $)$

\begin{tabular}{|l|r|r|r|}
\hline Bulan Tahun & $\begin{array}{c}\text { Indeks Waktu } \\
(\mathrm{t})\end{array}$ & Penjualan Aktual (A) & $\begin{array}{r}\text { Ramalan berdasarkan ES }(\alpha=1 \\
0,8) \\
(\mathrm{F}, \text { ES } \alpha=0,8)\end{array}$ \\
\hline Mei 2019 & 17 & 86 & $94+0,8(79-94)=82$ \\
\hline Juni 2019 & 18 & 98 & $82+0,8(86-82)=85$ \\
\hline Juli 2019 & 19 & 79 & $85+0,8(98-85)=95$ \\
\hline Agustus 2019 & 20 & 90 & $95+0,8(79-95)=82$ \\
\hline September 2019 & 21 & 83 & $85+0,8(90-82)=88$ \\
\hline Oktober 2019 & 22 & 97 & $88+0,8(83-88)=84$ \\
\hline November 2019 & 23 & 88 & $84+0,8(97-84)=94$ \\
\hline Desember 2019 & 24 & 97 & $94+0,8(88-94)=89$ \\
\hline Januari 2020 & 25 & 88 & $89+0,8(97-89)=95$ \\
\hline Februari 2020 & 26 & 75 & $78+0,8(88-95)=89$ \\
\hline Maret 2020 & 27 & 87 & $89+0,8(75-89)=78$ \\
\hline April 2020 & 28 & 69 & $78+0,8(87-78)=85$ \\
\hline Mei 2020 & 29 & 75 & $85+0,8(69-85)=72$ \\
\hline Juni 2020 & 30 & 103 & $72+0,8(75-72)=74$ \\
\hline Juli 2020 & 31 & 114 & $74+0,8(103-74)=97$ \\
\hline Agustus 2020 & 32 & 120 & $97+0,8(114-97)=111$ \\
\hline September 2020 & 33 & 100 & $111+0,8(120-111)=118$ \\
\hline Oktober 2020 & 34 & 115 & $118+0,8(100-118)=104$ \\
\hline November 2020 & 35 & 117 & $104+0,8(115-104)=113$ \\
\hline Desember 2020 & 36 & 131 & $113+0,8(117-113)=116$ \\
\hline Januari 2021 & 37 & $?$ & $116+0,8(131-116)=128$ \\
\hline
\end{tabular}

Sumber: Pengolahan Data, 2020

Tabel 4. merupakan peramalan dengan menggunakan metode pemulusan eksponensial kita dapat mengetahui hasil forecast dimasa yang akan datang yaitu 128 Kotak. Untuk mengetahui sejauh mana keandalan dari model peramalan yang digunakan, langkah selanjutnya adalah membuat peta kontrol tracking signal. Perhitungan nilai-nilai tracking signal untuk model pemulusan eksponensial dengan konstanta pemulusan $\alpha=0.8$. Untuk mengetahui sejauh mana keandalan dari model forecast yang digunakan, Langkah selanjutnya adalah menguji keandalan forecast atau peramalan menggunakan peta kontrol tracking signal. Perhitungan tracking signal untuk model exponential smoothing yang dapat dihitung dengan cara:

a. Nilai Error

Error $=$ Aktual - Forecast $=131-16=15$

b. Nilai RSFE

RFSE $=$ Kumulatif nilai error $=44$

c. Absolut Error

Absolut error $=$ nilai mutlak dari error $=15$

d. Kumulatif Absolut Error

Kumulatif absolut error $=423$

e. Nilai Mean Absolute Deviation (MAD)

MAD $=$ Kumulatif absolut error (kumulatif) / Periode

$\mathrm{MAD}=423 / 36=12$

f. Tracking Signal

Tracking signal $=\mathrm{RSFE} / \mathrm{MAD}=44 / 12=3,71$ 
Hasil perhitungan tracking signal untuk model pemulusan eksponensial $\alpha=0,8$ ditunjukkan pada lampiran 32. Untuk grafik tracking signal dari model pemulusan eksponensial $(\alpha=0,8)$ dapat dilihat pada Gambar 4 .

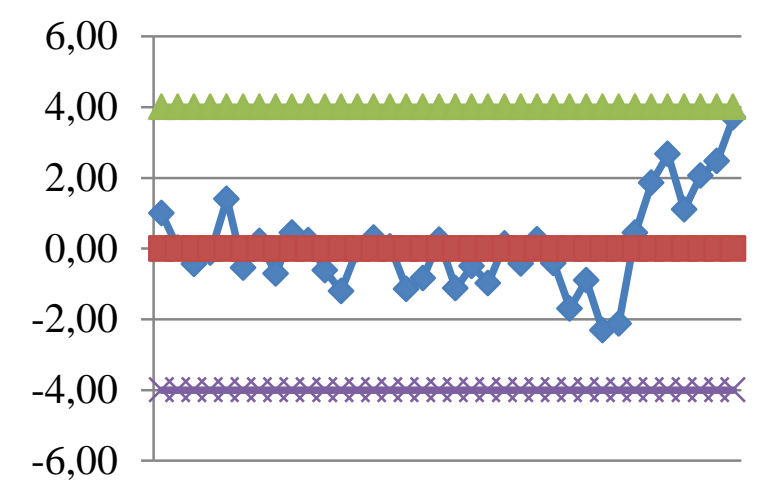

Gambar 4.. Peta Kontrol Tracking Signal Exponential Smoothing $(\alpha=0,8)$

Sumber: Pengolahan Data, 2020

Gambar 4. menunjukkan bahwa nilai-nilai tracking signal untuk model forecast dengan menggunakan metode pemulusan eksponensial dengan menggunakan konstanta pemulusan $\alpha=0,8$. berada dalam batas-batas yang dapat diterima (maksimum \pm 4 ), dimana nilai-nilai tracking signal itu bergerak dari -2 sampai +3 . Hal ini menunjukkan bahwa akurasi dari model pemulusan eksponensial dapat diandalkan. Berdasarkan pengujian kehandalan dari model pemulusan eksponensial (Exponensial Smoothing) menggunakan tracking signal, penulis memutuskan untuk menggunakan model pemulusan eksponensial (exponensial smoothing) sebagai metode forecasting yang tepat untuk memprediksi penjualan kertas untuk periode kedepannya dengan nilai ramalan 128 kotak. Selanjutnya grafik perbandingan nilai aktual dan peramalan penjualan Kertas (exponential smoothing $\alpha=0,8$ ) dapat dilihat pada Gambar 5.

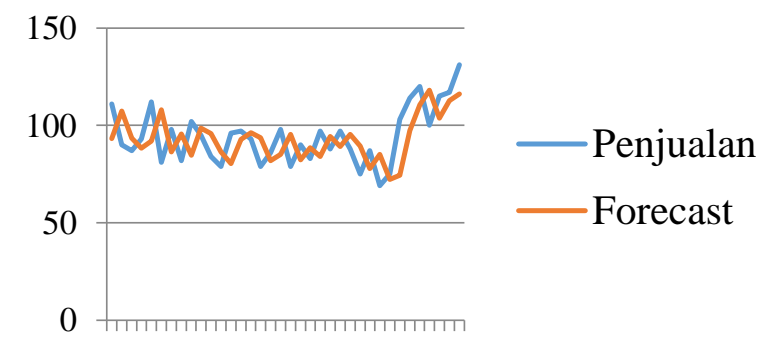

Gambar 5. Grafik Perbandingan Nilai Penjualan Aktual dan Hasil Forecast Sumber: Pengolahan Data, 2020

Gambar 5 merupakan grafik perbandingan nilai aktual dan hasil peramalan penjualan Kertas periode Januari 2018 sampai Desember 2020. Dimana nilai aktual dan ramalan tersebut hampir mirip dan berada dalam batas-batas yang dapat diterima. Sehingga metode ini cocok digunakan untuk menentukan nilai penjualan kertas periode berikutnya. Setelah melakukan pengolahan data dan perhitungan hasil peramalan menggunakan model pemulusan pemulusan eksponensial untuk bulan November 2020 sebesar 128 kotak. Maka jumlah estimasi kebutuhan jumlah kertas untuk 1 tahun kedepan adalah 128 × $12=1536$ kotak. Langkah selanjutnya ialah membuat persamaan untuk rata-rata persediaan. 
Rata-rata Persediaan $=\frac{\text { persediaan }+ \text { persediaan akhir }}{2}$

$$
=\frac{(\mathrm{Q}+0)}{2}=\mathrm{Q} / 2
$$

Jadi, persamaan untuk rata-rata persediaan yaitu $Q / 2$. Selanjutnya mencari persamaan untuk rata-rata biaya simpan.

Rata-rata biaya simpan $=\mathrm{Q} / 2 \times \mathrm{h}=\mathrm{Q} / 2 \times 31.000=15.500 \mathrm{Q}$

Persamaan untuk rata-rata biaya simpan yaitu 15.500 Q. Selanjutnya mencari persamaan untuk total biaya pemesanan.

Total biaya pemesanan $=\mathrm{A} \frac{\mathrm{D}}{\mathrm{Q}}$

$$
=20.000 \frac{1536}{\mathrm{Q}}=30.720 .000 / \mathrm{Q}
$$

Persamaan untuk total biaya pemesanan adalah 30.720.000/Q. Lalu menghitung total biaya yang harus dikeluarkan dengan rumus:

Total Biaya $=$ Biaya simpan + biaya pesan

$$
=15.500 \mathrm{Q}+30.720 .000 / \mathrm{Q}
$$

Jadi, persamaan untuk total biaya menjadi $15.500 \mathrm{Q}+30.720 .000 / \mathrm{Q}$.

Selanjutnya menghitung EOQ untuk kertas dengan rumus:

$\mathrm{EOQ}=\sqrt{\frac{2 \mathrm{AD}}{\mathrm{h}}}=\sqrt{\frac{2 \times 20.000 \times 1.536}{31.000}}=\sqrt{\frac{61.440 .000}{31.000}}=\sqrt{1.982}=45$ kotak

Jadi EOQ untuk Kertas HVS adalah sebanyak 45 kotak. Selanjutnya untuk perhitungan persediaan dapat dilihat pada Tabel 5.

Tabel 5. Hitungan Biaya Persediaan

\begin{tabular}{|r|r|r|r|}
\hline $\begin{array}{c}\text { Kuantitas pesanan } \\
(\mathrm{Q})\end{array}$ & $\begin{array}{c}\text { Biaya simpan } 15.500 \\
\mathrm{Q}\end{array}$ & $\begin{array}{c}\text { Biaya pesanan } \\
\text { 30.720.000/Q }\end{array}$ & Total biaya \\
\hline 41 & 635500 & 749268 & 1384768 \\
\hline 42 & 651000 & 731429 & 1382429 \\
\hline 43 & 666500 & 714419 & 1380919 \\
\hline 44 & 682000 & 698182 & 1380182 \\
\hline 45 & 697500 & 682667 & 1380167 \\
\hline 46 & 713000 & 667826 & 1380826 \\
\hline 47 & 728500 & 653617 & 1382117 \\
\hline 48 & 744000 & 640000 & 1384000 \\
\hline 49 & 759500 & 626939 & 1386439 \\
\hline 50 & 775000 & 614400 & 1389400 \\
\hline
\end{tabular}

Sumber: Pengolahan Data, 2020

Tabel 5 menunjukkan bahwa banyaknya pesanan yang paling ekonomis sebesar 45 kotak, hal ini terbukti total biaya pengelolaan persediaan, yang menunjukkan perhitungan biaya pesan dan biaya simpan yang paling efisien, yaitu sebesar Rp. 1.380.167,-. Setelah diketahui kuantitas pesanan Q untuk kertas pada tingkat EOQ, melengkapi model ini dibutuhkan penentuan waktu tunggu (lead time) antara waktu 
pesan sampai barang diterima. Misalnya, masa tunggu dalam waktu 4 hari sejak barang dipesan sampai diterima digudang. Oleh karena adanya waktu tunggu (lead time) maka dibutuhkan adanya persediaan yang dicadangkan untuk masa tunggu jangan sampai persediaan dalam kondisi kosong baru memesan barang, karena kondisi ini akan mengganggu kesinambungan proses produksi. Oleh karena itu, perusahaan membutuhkan persediaan pengaman. Besarnya bisa ditentukan berdasarkan masa tunggu pesanan melalui persamaan, yaitu:

Persediaan pengaman $=\frac{\mathrm{D}}{360} \mathrm{x}$ lead time

Persediaan pengaman $=\frac{1536}{360} \times 4$ hari $=17$ Kotak

Dengan demikian, pemesanan kembali yaitu pada kondisi tingkat persediaan pengaman ditambah kuantitas pemesanan pada tingkat EOQ yaitu sebesar $45+17=62$ kotak.Selanjutnya menghitung reoder point (ROP) yaitu titik jumlah pemesanan kembali atau untuk menentukan berapa batas minimal tingkat persediaan yang harus dipertimbangkan sehingga tidak terjadi kekurangan.

ROP $=$ D x L $=(1536 / 312) \times 4=20$ kotak

Artinya CV Surya Niaga Jaya harus melakukan pemesanan kertas pada waktu jumlah persediaan kertas tinggal 20 kotak. Selanjutnya perhitungan untuk maksimum stok adalah sebagai berikut:

Maksimum stok = EOQ $+\mathrm{SS}+\mathrm{z}$

$\mathrm{z}$ didapat dari kebutuhan selama lead time yaitu:

$\mathrm{z}=\mathrm{L} \times \frac{\mathrm{S}}{12}=4 \mathrm{x} \frac{128}{12}=43$

Maka maksimum stok $=45+17+43=105$ Kotak.

Selanjutnya grafik pengendalian persediaan kertas di CV Surya Niaga Jaya dapat dilihat pada Gambar 6

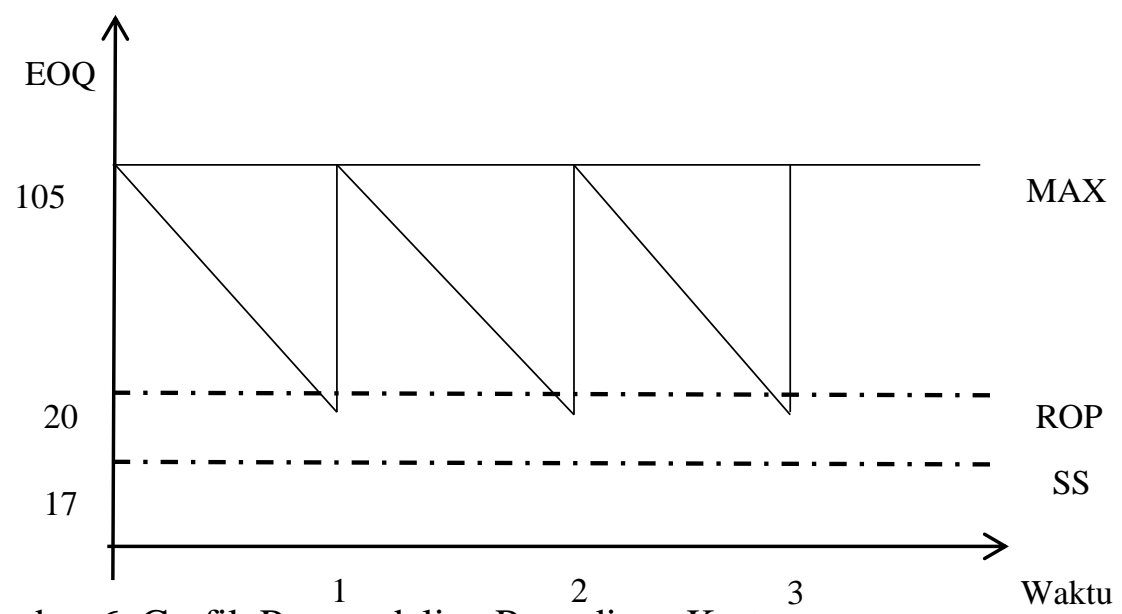

Gambar 6. Grafik Pengendalian Persediaan Kertas

Sumber: Pengolahan Data, 2020

Gambar 6 menunjukkan bahwa jumlah maksimum stok kebutuhan kertas bulan Desember sebesar 105 kotak, untuk melakukan pemesanan kembali pada saat jumlah 
kertas didalam gudang sebanyak 20 kotak dan jumlah safety stock sebesar 17 kotak dengan lead time 4 hari untuk bisa dilakukan pengadaan persediaan.

\section{Kesimpulan}

Berdasarkan hasil pengolahan dan analisis data yang telah dilakukan, maka dapat diambil kesimpulan peramalan persediaan pena di CV Surya Niaga Jaya untuk periode Januari 2021 adalah sebanyak 45 kotak dan kertas 128 kotak. Untuk economic order quantity (EOQ) dari pena adalah 26 kotak dan kertas 45 kotak. Persediaan pengaman atau safety stock pena adalah 6 kotak dan kertas 17 kotak. Sedangkan untuk pemesanan kembali pena dengan 32 kotak lalu reorder point (ROP) adalah 7 kotak dan untuk maksimum stok pena adalah 47 kotak dan untuk pemesanan kembali kertas dengan 62 kotak lalu reorder point (ROP) adalah 20 kotak dan untuk maksimum stok kertas adalah 10 kotak.

\section{Daftar Pustaka}

Fitra., Khairani, M., dan Indrawan, S., 2020, Perencanaan Persediaan Bahan Bakar Minyak PT X, JURNAL UNITEK, 12(1), 1-9.

Gaspersz, 2008, Production Planning and Inventory Control, PT Gramedia Pustaka Utama, Jakarta..

Harmono., 2014, Manajemen Keuangan, Berbasis Balanced Scorecard, Pendekatan Teori, Kasus, dan Riset Bisnis, Bumi Aksara, Hal 219-222.

Herlambang, A, 1., dan Dewi, R., 2017, Pengendalian Persediaan Bahan Baku Beras dengan Metode Economic Order Quantity (EOQ) Multi Produk Guna Meminimumkan Biaya (Studi Kasus pada CV. Lumbung Tani Sejahtera), Jurnal Ekonomi dan Bisnis, Vol. 2 (2), Hal: 525-542.

Ismaniah., Salkiawati, R., Rasim., dan Rejeki, S., 2018, Sistem Informasi Pengendalian Persediaan Alat Tulis Kantor (ATK) di Universitas, Jurnal Rekayasa Informasi, ISSN: 2252-7354, Vol. 7 (2), Hal: 63-70.

Khairani, D, S,. 2013, Perencanaan dan Pengendalian Produksi, Graha Ilmu, Yogyakarta

Mesra, T., Melliana, dan Sitorus, A.A., (2021), Perencanaan Persedian Argon Di Cv Cahaya Teknik Abadi Jurnal ARTI (Aplikasi Rancangan Teknik Industri), VOL.16 NO 1 (2021) Desember 2020 - Mei 2021, Hal: 72-78

Mesra, T., Fitra, dan Anggraini, R., Pengendalian Persediaan Bahan Pendukung Pemurnian Minyak Sawit di PT XYZ, Buletin Utama Teknik, Volume 15 No. 1, Bulan September.

Putra, M, S., dan Solikin, I., 2019, Aplikasi Peramalan Stok Alat Tulis Kantor (ATK) Menggunakan Metode Single Moving Average (SMA) pada PT. Sinar Kencana Multi Lestari, Journal of Computer Engineering System and Science, ISSN: 2502-7131, Vol. 4 (2), Hal: 236-241.

Rachman., R., 2018, Penerapan Metode Moving Average dan Exponential Smoothing pada Peramal Produksi Industri Garment, Jurnal Informatika, ISSN: 2355-6579, Vol. 5 (1), Hal: 211-220.

Sinulingga, S (2017), Perencanaan dan Pengendalian Produksi, USU Press, Medan

Zulfikar, A., Parinduri, L., dan Hasibuan, A., 2020, Analisis Persediaan Kayu dengan Metode Economic Order Quantity (EOQ), Fakultas Teknik, ISSN: 1410-4520, Vol. 15 (3), Hal: 234-240. 